\title{
Water movements after an intraruminal water load in pregnant and lactating Sardi sheep
}

\author{
S Benlamlih *, M Oukessou \\ Institut Agronomique et Vétérinaire Hassan II, Departement de physiologie et Thérapeutique, \\ BP 6202, Rabat-Instituts. Morocco
}

(Received 4 September 1989; accepted 12 January 1990)

\begin{abstract}
Summary - The effects of an intraruminal load of 3 litres of water on body water movements was compared in Sardi sheep during the last month of pregnancy, lactation and a non-pregnant, nonlactating control period. Before the water load, rumen fluid volume, estimated by polyethylene glycol was similar in pregnant, compared to control, animals and $27 \%$ higher in lactating sheep. After the water load, rumen volume returned to pre-hydration level in $1 \mathrm{~h}$ during pregnancy, after $3 \mathrm{~h}$ during lactation and in the control period. Rumen osmolality decreased by $40 \%$ and remained at this low level for $3 \mathrm{~h}$ after the water load in all physiological periods. When the water load was tritiated water (TOH), the rate of TOH transfer into plasma was faster during the last month of pregnancy than during the control period. Plasma osmolality and proteins decreased in response to the water load. No differences in these responses were observed between pregnancy, lactation and the control period. Water diuresis began in the first $\mathbf{3 0}$ min following the water load in pregnant ewes and in the second $30 \mathrm{~min}$ in lactating and control ewes. The diuresis was also more pronounced in pregnant, than in non-pregnant, states. These results indicate that water is more rapidly absorbed from the gastrointestinal tract in pregnant, rather than in non-pregnant, sheep. This may partly explain the increased water turnover seen during pregnancy.
\end{abstract}

\section{rumen / water / pregnancy / lactation / sheep}

Résumé - Mouvements d'eau après une charge intraruminale d'eau chez les brebis Sardi gestantes et allaitantes. Les effets d'une charge intraruminale de 3 I d'eau sur les mouvements d'eau corporelle ont été comparés chez des brebis Sardi durant le dernier mois de gestation, durant la lactation et au cours d'une période de contrôle. Avant la charge hydrique, le volume du fluide ruminal estimé par le polyéthylène glycol a été similaire chez les brebis gestantes et les brebis de contrôle et plus grand de $27 \%$ chez les brebis allaitantes. Après la charge hydrique, le volume du fluide ruminal est retourné aux valeurs de pré-hydratation en $1 \mathrm{~h}$ durant la gestation et en $3 \mathrm{~h}$ durant la lactation et la période de contrôle. L'osmolalité ruminale a baissé de $40 \%$ et est restée à ce niveau durant $3 \mathrm{~h}$ après la charge hydrique au cours de tous les stades physiologiques. Lorsque la charge hydrique a été réalisée avec de l'eau tritiée (TOH), la vitesse de transfert de TOH vers le plasma a été plus rapide durant le dernier mois de gestation que durant la période de contrôle. L'osmolalité et le taux de protéines plasmatiques ont diminué en réponse à la charge hydrique, mais ces variations n'ont pas été différentes entre les 3 stades physiologiques. La diurèse hydrique a démarré dans la première demi-heure suivant la charge hydrique chez les brebis gestantes et dans la seconde demi-heure chez les allaitantes et les brebis de contrôle. La diurèse a été aussi plus prononcée chez les gestantes que chez les non gestantes. Les résultats suggèrent que l'eau bue est absorbée plus rapidement du tractus digestif au cours de la gestation. Cela peut expliquer en partie l'accroissement du renouvellement d'eau corporelle se produisant durant la gestation.

rumen / eau / gestation / lactation / brebis

\footnotetext{
* Correspondence and reprints
} 


\section{INTRODUCTION}

Water intake increases during pregnancy in goats (Olsson et al, 1982) and sheep (Benlamlih et al, 1985; Michell et al, 1988), and this is accompanied by excretion of large amounts of diluted urine. The augmented water turnover appears to be caused partly by a primary stimulation of thirst and partly by a decreased renal ability to concentrate the urine (Benlamlih, 1984).

During lactation, water intake is enhanced and this has been related to milk production (Davies, 1972), although recent studies in lactating goats indicate that they drink in excess of their needs (Dahlborn, 1987).

The rumen represents a large reservoir for water. In spite of a large water diffusion across the rumen wall, the transepithelial net movement of water was reported to be small (Engelhardt, 1970). The rate of net water absorption of ingested water from gastro-intestinal tract to blood plasma may be greater if rumen fluid is transported more rapidly to the posterior parts of the gastro-intestinal tract. Due to compression by the gravidic uterus, it was shown that rumen volume is reduced during late pregnancy in sheep (Forbes, 1968, 1969), and an increased liquid outflow from the rumen was reported to occur during late pregnancy (Weston, 1979). Therefore, a more rapid rate of absorption of ingested water may be expected during late pregnancy. To investigate this hypothesis, the rumen volume was measured before and after an intraruminal water load in pregnant, lactating and non-pregnant, non-lactating (= control period) ewes. Furthermore, the activity of tritiated water (TOH) in blood plasma, after an intraruminal load of water labelled with $\mathrm{TOH}$, was compared for the 3 physiological states.

\section{MATERIALS AND METHODS}

\section{Animals and feeding}

Ewes of the Sardi breed were used. This breed is found in the semi-arid region of Tadla (Morocco). The animals were kept in metabolism cages and usually fed $500 \mathrm{~g}$ of hay and $200 \mathrm{~g}$ of grain at $830 \mathrm{~h}$ and $1700 \mathrm{~h}$. In the afternoon, $6 \mathrm{~g} \mathrm{NaCl}$ and $10 \mathrm{~g}$ of a commercial mixture of vitamins and minerals were added to the grain. The room temperature was $15-23{ }^{\circ} \mathrm{C}$ and relative humidity was $60 \pm 5 \%$. The ewes usually had free access to water. On the experimental days, the animals were fed at $700 \mathrm{~h}$ and allowed to drink post prandially. At $1000 \mathrm{~h}$, the water bucket was removed.

All ewes delivered singletons. Lambs were kept with their mothers in the metabolism cages during the first 7-8 weeks. The lambs were then removed, and after 3-6 wks, when the ewes were completely dried, they were subjected to the control experiments.

\section{Rumen fluid volume measurement}

Three ewes with rumen cannulas were used (body weights $30-36 \mathrm{~kg}$ in control period, $36-45$ $\mathrm{kg}$ in pregnancy and $30-40 \mathrm{~kg}$ in lactation). Each animal was subjected to 3 experiments during the last month of pregnancy, 2 during lactation and 3 during the control period.

On experimental days, at $1000 \mathrm{~h}, 100 \mathrm{ml}$ of a $2 \%$ polyethylene glycol (PEG 4000 , Merck) solution was put into the rumen through the cannula. To ensure good mixing with the rumen fluid, the solution was spread in different parts of the rumen, and the abdomen of the ewes was vigorously massaged manually for 4-5 min after the injection of PEG. Rumen fluid samples were taken before introducing the marker and immediately after the massage of the rumen. Each sample contained $20-40 \mathrm{ml}$ of rumen fluid withdrawn from 3 different parts of the rumen (atrium, dorsal sac and ventral sac). The samples were immediately filtered through a gauze and then centrifuged. The supernatant was conserved for analysis. 
After the first measurement of rumen fluid volume, 3 litres of water $\left(39^{\circ} \mathrm{C}\right)$ were introduced into the rumen through the cannula and the abdomen massaged as described above. A rumen sample was taken immediately after the massage. Rumen volume measurements were then repeated after 1, 2 and $3 \mathrm{~h}$ using the same protocol described earlier, except that only $50 \mathrm{ml}$ of the PEG solution was given.

To evaluate the efficiency of mixing, 4 experiments were performed in control sheep during steady-state conditions. The rumen volume was measured as described above. In addition, rumen fluid samples were taken at $1,2,3$ and $4 \mathrm{~h}$ after the introduction of the marker, and the PEG concentration at zero time was calculated from the regression curve.

\section{TOH activity in blood plasma}

Four ewes were used (body weights $41.45 \mathrm{~kg}$ in control period, $44-51 \mathrm{~kg}$ in pregnancy and $41-47$ $\mathrm{kg}$ in lactation). Each animal was subjected to 23 water load experiments during the last month of pregnancy, during lactation (20-40 d after parturition) and during the control period. An interval of at least $8 \mathrm{~d}$ was allowed between the $2 \mathrm{ex}$ periments.

On the experimental day, a polyethylene cannula was introduced into 1 of the jugular veins and a retention catheter was placed in the urinary bladder. After a control blood sample had been taken and urine had been collected for a 30-min period, the animals received 3 litres of warm water $\left(39^{\circ} \mathrm{C}\right)$ in the rumen by stomach tube. The first 2.5 litres contained $200 \mu \mathrm{Cl}$ of $\mathrm{TOH}$ (Amersham, England). The remaining 0.5 litre ensured that all radioactivity remaining in the stomach tube was washed into the rumen. The abdomen was then massaged as described above. Blood samples were taken at 10, 20, 30, $40,50,60,90,120,150,180,240,300,360$ and 420 min after intraruminal loads with labelled water. Urine was collected at $30 \mathrm{~min}$-intervals for $3 \mathrm{~h}$.

When the final blood sample had been taken, the water bucket was replaced in front of the animals and the afternoon meal offered.

\section{Analysis}

The ruminal concentration of polyethylene glycol was analysed in triplicate, according to the method described by Hyden (1955).

Aliquots of $1 \mathrm{ml}$ of plasma were transferred to scintillation vials and mixed with $15 \mathrm{ml}$ of liquid scintillator (Scintiverse E, Fisher Company). The vials were placed in a liquid scintillator counter and estimated for the radioactivity of the plasma. Correction for quenching was made by means of the external channel-ratio.

The osmolality of plasma, urine and rumen fluid was determined on a Knauer automatic osmometer. The total plasma proteins were measured with a refractometer (TS meter, American Optical).

\section{Calculations and statistics}

The rumen volume $V$ was calculated according to Hyden (1961) :

$$
V=(Q-L \times C 2) /(C 2-C 1)
$$

where $Q$ is the amount of polyethylene added into the rumen, $\mathrm{C}_{1}$ and $\mathrm{C}_{2}$, the concentration immediately before and after the dosage, and $L$, the volume of water added with polyethylene glycol.

The transfer of HTO from rumen to plasma, after intraruminal TOH loading, could be described by first-order kinetics (Holtenius, 1989). Thus, the rate constant for the TOH transfer could be calculated according to the equation:

$$
A_{e}-A_{t}=A_{e} e^{-k t}
$$

$A_{t}$ : the plasma TOH activity at time $t$ (samples taken at $10,20,30,40,50,60 \mathrm{~min}$ after water load).

$A_{e}$ : the equilibrium plasma activity (mean $\mathrm{TOH}$ activity of samples taken at 360 and 420 min after the water load).

$k$ : rate constant for HTO transfer from rumen to plasma. 
The back flow of TOH from plasma to rumen was not compensated for, since the ruminal TOH concentration was much higher than plasma TOH concentration during the 60 min measurement period (Holtenius, 1989). The model was fitted to the data by exponential regression and $\mathrm{k}$ value, estimated for each experiment.

The results obtained during pregnancy and lactation were compared with those of the control period by the Student $t$-test. Values are given as means \pm SEM.

\section{RESULTS}

\section{Changes in rumen fluid volume}

Morning post-prandial drinking before water loading was $1.0 \pm 0.2$ I during the con- trol period; $1.8 \pm 0.3 \mid(P<0.05)$ during pregnancy, and $1.2 \pm 0.21$ (NS) during lactation.

Rumen osmolality decreased after the intraruminal water load to about 0.15 osm. $\mathrm{kg}^{-1}$ during all 3 periods (fig 1). For $3 \mathrm{~h}$ after the water load, rumen osmolality was maintained at this low level. Values of corresponding samples were not statistically different during pregnancy, lactation and the control period.

Before the water load, rumen fluid volume was similar in pregnant and control animals and $27 \%$ larger in lactating sheep (fig 1). During lactation and the control period, rumen volume decreased gradually after the water load with the slowest

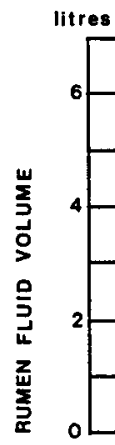

CONTROL $(n=9)$
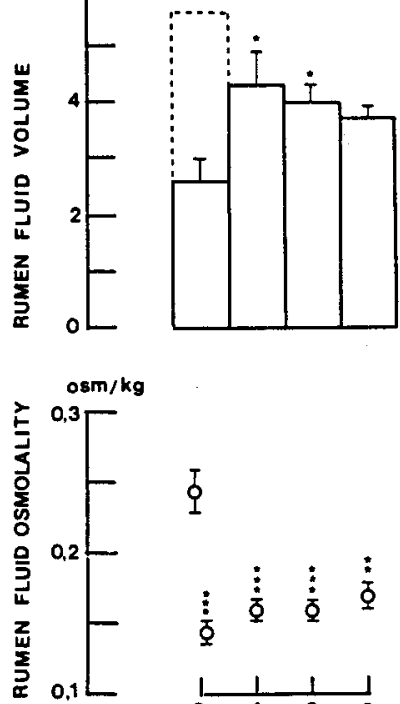

PREGNANCY $(n=9)$

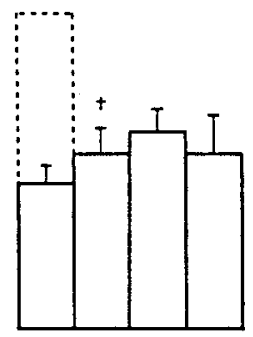

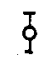

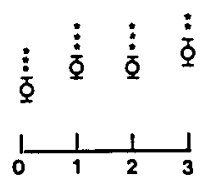

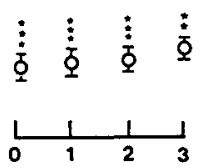

LACTATION $(n=6)$
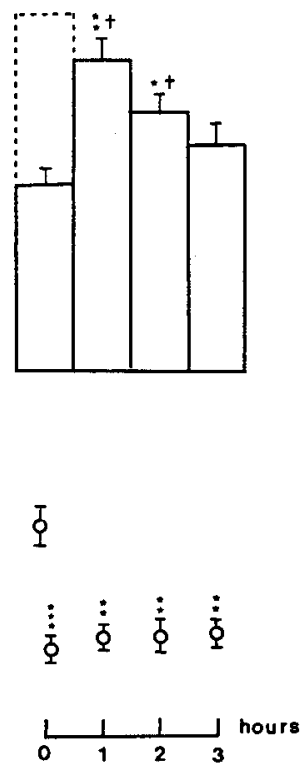

Fig 1. Changes in rumen fluid volume and osmolality after intraruminal water load $\left(3 \mid\right.$ at $\left.39^{\circ} \mathrm{C}\right)$. In the top figure, broken lines represent the water vol, added immediately after measurement of rumen volume at time 0 . Asterisks indicate significant differences with pre-hydration values during each physiological state $\left({ }^{*} P<0.05,{ }^{* *} P<0.01,{ }^{* * *} P<0.001\right)$. Crosses refer to significant differences between pregnancy or lactation, and the corresponding values during the control period $(\dagger P<0.05$ ). Mean \pm SE. 
change in lactating ewes. In pregnant sheep, rumen volume was back to prehydration value $1 \mathrm{~h}$ after the intraruminal water load.

The evaluation of the method of rapid mixing of the marker gave the following results: the volumes calculated from the samples taken immediately after massaging the abdomen were $3.4,3.0,3.0$ and 3.8 litres. The corresponding values, calculat- ed by extrapolation from the concentration curve, were 3.4, 3.0, 3.2 and 3.9 litres.

\section{Experiments on the transfer rate of TOH into blood plasma}

The kinetics of plasma $\mathrm{TOH}$, expressed as $\%$ of the equilibration value, is shown in figure 2. The increase in plasma $\mathrm{TOH}$ ac-

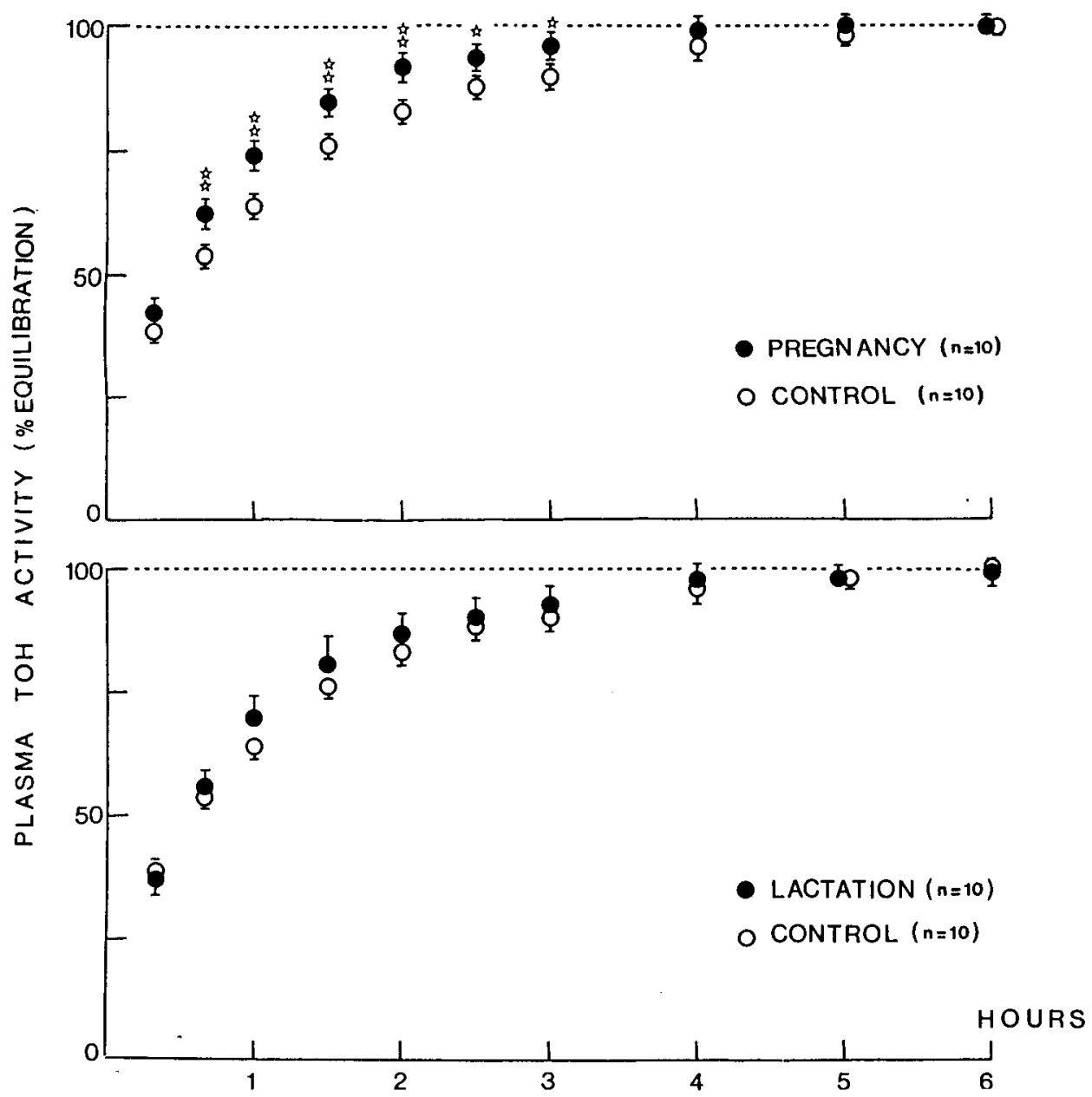

Fig 2. Increase in plasma TOH activity (as \% of equilibration value) after intraruminal load of 3 I of water labelled with $\mathrm{TOH}$ during the control period, during pregnancy and during lactation. Stars refer to significant difference between pregnancy or lactation and the corresponding values during the control period $\left({ }^{\star} P<0.05,{ }^{\star \star} P<0.01\right)$. Mean \pm SE. 
tivity was faster during the last month of pregnancy compared to the control period.

The rate of $\mathrm{TOH}$ transfer from rumen to plasma was $1.4 \pm 0.1 \% \cdot \mathrm{min}^{-1}$ during the control period, $2.1 \pm 0.1 \% \cdot \mathrm{min}^{-1}(P<0.01)$ during pregnancy and $1.8 \pm 0.1 \% \cdot \mathrm{min}^{-1}$ (NS) during lactation.

Before the water load, total plasma protein was lowered during both pregnancy and lactation, while plasma osmolality was similar during pregnancy, lactation and the control period (table 1). The intraruminal water load induced a decrease in these 2 blood parameters. No significant differences in these responses were observed between pregnancy, lactation and the control period.

Before the intraruminal water load, urine flow was higher and urine osmolality lower in pregnant, than in control, animals (fig 3). Intraruminal administration of 3 litres of water induced a water diuresis in all animals, but the urine flow increased more rapidly and became more pronounced dur- ing pregnant, compared with nonpregnant, states.

\section{DISCUSSION}

The determination of rumen volume after rapid mixing of the marker corresponded well with the values obtained (during steady-state conditions) by extrapolation to zero time from the concentration curve. This first method, already used by Choshniak and Shkolnik (1977), allowed measurements during non-steady state conditions with large variations in rumen volume, but could not be used for accurate determination of outflow from the rumen.

In agreement with previous observations in goats (Olsson et al, 1982), intraruminal water loads in Sardi ewes induced a faster urine excretion of the excess water during pregnancy than during a nonpregnant state. This might be explained by a more rapid absorption of water from the gastro-intestinal tract to plasma during

Table I. Plasma osmolality and total plasma proteins during the control period $(n=10)$, during pregnancy $(n=10)$ and during lactation $(n=10)$. The values represent the initial levels and the net variation after an intraruminal load of 3 litres of water. Asterisks refer to $t$-test comparison with the control period ( $\left.P<0.05 ;{ }^{* \star} P<0.01\right)$. Mean $\pm S E$.

\begin{tabular}{|c|c|c|c|c|c|c|}
\hline & $O \min$ & $20 \mathrm{~min}$ & $40 \mathrm{~min}$ & $60 \mathrm{~min}$ & $120 \mathrm{~min}$ & $180 \mathrm{~min}$ \\
\hline \multicolumn{7}{|l|}{$\begin{array}{l}\text { Plasma osmolality } \\
\text { (mosmoløkg }\end{array}$} \\
\hline $\begin{array}{l}\text { Control period } \\
\text { Pregnancy } \\
\text { Lactation }\end{array}$ & $\begin{array}{l}295 \pm 2 \\
296 \pm 2 \\
294 \pm 3\end{array}$ & $\begin{array}{l}-2 \pm 1 \\
-4 \pm 2 \\
-0 \pm 2\end{array}$ & $\begin{array}{l}-2 \pm 1 \\
-4 \pm 2 \\
-2 \pm 2\end{array}$ & $\begin{array}{l}-1 \pm 2 \\
-4 \pm 3 \\
-2 \pm 1\end{array}$ & $\begin{array}{l}-2 \pm 1 \\
-6 \pm 2 \\
-3 \pm 2\end{array}$ & $\begin{array}{l}-5 \pm 1 \\
-6 \pm 3 \\
-5 \pm 2\end{array}$ \\
\hline \multicolumn{7}{|l|}{$\begin{array}{l}\text { Plasma proteins } \\
\left(g^{\prime} 1^{-1}\right)\end{array}$} \\
\hline $\begin{array}{l}\text { Control period } \\
\text { Pregnancy } \\
\text { Lactation }\end{array}$ & $\begin{array}{l}70 \pm 0 \\
64 \pm 2\left(^{*}\right) \\
63 \pm 1\left(^{* *}\right)\end{array}$ & $\begin{array}{l}-2 \pm 1 \\
-2 \pm 0 \\
-2 \pm 0\end{array}$ & $\begin{array}{l}-2 \pm 1 \\
-2 \pm 1 \\
-2 \pm 1\end{array}$ & $\begin{array}{l}-1 \pm 1 \\
-2 \pm 0 \\
-2 \pm 1\end{array}$ & $\begin{array}{l}-2 \pm 1 \\
-2 \pm 3 \\
-1 \pm 1\end{array}$ & $\begin{array}{l}-1 \pm 1 \\
-1 \pm 1 \\
-1 \pm 0\end{array}$ \\
\hline
\end{tabular}




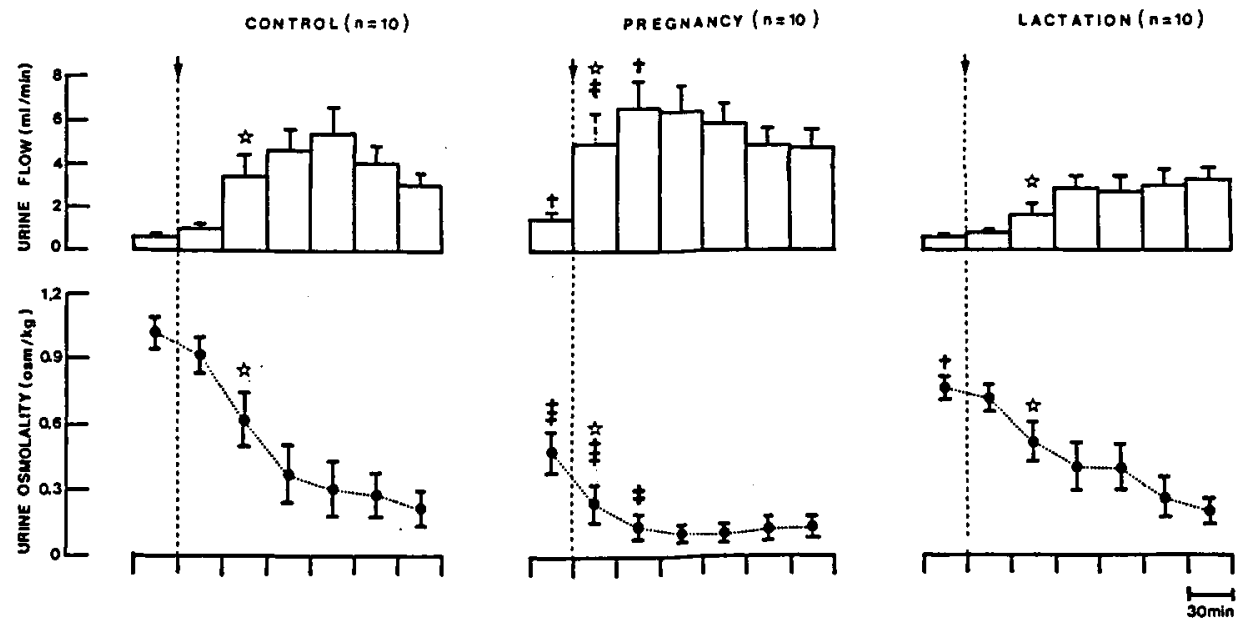

Fig 3. Effects of intraruminal water load $\left(3 \mid\right.$ at $\left.39^{\circ} \mathrm{C}\right)$ on urine volume and urine osmolality during the control period, during pregnancy and during lactation. The crosses refer to a significant difference between control period and corresponding values during pregnancy and lactation $(\dagger P<0.05$, $\dagger+P<$ $0.01, t+\dagger P<0.001$ ). The stars refer to the time at which urine flow and urine osmolality became significantly different $(P<0.05)$ from the pre-hydration value. Mean $\pm S E$.

pregnancy, leading to a more rapid excretion of water by the kidneys. In favour of this hypothesis, is the fact that the rate of $\mathrm{TOH}$ transfer from rumen to plasma was higher during pregnancy, than during the control period. A faster absorption of water during pregnancy would have induced a more pronounced hemodilution. However, the changes in plasma osmolality and plasma proteins were similar during the 3 physiological states. This can be related to the rapid renal excretion of water seen during pregnancy resulting from the reported decrease in the ability of the kidneys to concentrate urine (Benlamlih, 1984) and fast plasma clearance rate for the argininevasopressin (Wintour et al, 1987).

The faster return of rumen volume to pre-hydration level in pregnant ewes indicates either a fast net water absorption over the rumen wall, or quick bypass to the lower part of the gastro-intestinal tract. In a recent study, net water absorption from the rumen was reported to be over 1 litre in 20 min in sheep (Holtenius, 1989), showing that great amounts of water can be absorbed through the rumen epithelium. The relatively large osmotic gradient, seen in the present study, between rumen fluid and plasma should have stimulated net water absorption from the rumen (Engelhardt, 1970). On the other hand, rumen osmolality was the same during pregnancy, lactation and the control period, and therefore, the net water absorption from the rumen caused by the osmotic gradient was probably the same during all 3 physiological states. However, it is possible that an elevated rumen blood flow, which has been reported to occur during pregnancy (Alexander et al, 1987), could have increased TOH clearance by producing a relatively high localized osmotic gradient (Dobson, 1984). 
Because rumen osmolality remained relatively constant for $3 \mathrm{~h}$ after the water load, the water was either absorbed secondarily to osmotically active solutes, as suggested by Dobson et al (1976), and/or transported out of the rumen with the solutes to the posterior parts of the digestive tract where the excess water could have been absorbed. In favour of the latter suggestion, is the observation that the residence time of water load in the rumen is reduced during pregnancy, most likely due to an increased pressure on the rumen by the gravidic uterus (Forbes, 1968, 1969).

During lactation, milk production involves a considerable strain on water balance, which can exceed that during pregnancy. Rumen volume was largest during lactation, and after the intraruminal water load, the decrease in rumen volume was slowest in this period. This indicates a prolonged retention time for water in the rumen of lactating ewes. The relatively low renal water excretion could also indicate a slower net water absorption from the digestive tract during lactation, compared to the control period. The rate of TOH transfer to plasma was, however, similar during lactation and the control period.

The results of the present study indicate that water is more rapidly absorbed from the gastro-intestinal tract during pregnancy. Together with an increased water intake and enhanced renal free water excretion, this could explain the increased water turnover in pregnant sheep. In contrast to the pregnancy condition, rumen capacity to store water was increased during lactation. This, in combination with the slow renal excretion of the water load, would attenuate the susceptibility of lactating sheep to shortage of water.

\section{ACKNOWLEDGMENTS}

This work was supported by the International Foundation for Science.

\section{REFERENCES}

Alexander G, Hales JRS, Stevens D, Donnelly JB (1987) Effects of acute and prolonged exposure to heat on regional blood flows in pregnant sheep. J Dev Physiol 9, 1-15

Benlamlih S (1984) Adjustments of fluid balance during pregnancy and lactation in small ruminants. PhD Thesis, Institut Agronomique et Veterinaire Hassan II, Rabat, Morocco

Benlamlih S, Bourkaik A, Belarbi A, Abouhala A (1985) Fluid balance in pregnant and lactating Dman ewes: effects of litter size, protein intake and inhibition of prostaglandin synthesis. Comp Biochem Physiol 80A, 591-597

Choshniak I \& Shkolnik A (1977) Rapid rehydratation in the Black Bedouin goats: red blood cells fragility and role of the rumen. Comp Biochem Physiol 56A, 581-583

Dahlborn K (1987) Effects of temporary food or water deprivation in the lactating goat. PhD Thesis, Sveriges Lantbruksuniversitet, Uppsala, Sweden

Davies PJ (1972) A note on the water intakeof ewes in late pregnancy and early lactation. Anim Prod 15, 307-310

Dobson A (1984) Blood flow and absorption from the rumen. Q J Exp Physiol 69, 599-606

Dobson A, Sellers AF, Gatewood H (1976) Dependence of Cr-EDTA absorption from the rumen on luminal osmotic pressure. $A m \mathrm{~J}$ Physiol 231, 1595-1600

Engelhardt WV (1970) Movement of water across the rumen epithelium. In: Physiology of Digestion and Metabolism in the Ruminant (Phillipson AT, ed) Oriel Press, Newcastle upon Tyne, 132-146

Forbes JM (1968) The physical relationships of the abdominal organs in the pregnant ewe. $J$ Agric Sci Cambridge 70, 171-177

Forbes JM (1969) The effect of pregnancy and fatness on the volume of the rumen contents in the ewes. J Agric Sci Cambridge 72, 119121

Holtenius K (1989) Water and electrolyte transport in the ruminant forstomach. PhD Thesis, Sveriges Lantbruksuniversitet, Uppsala, Sweden

Hyden S (1955) A turbidimetric method for the determination of higher polyethylene glycols 
in biological materials. Kungliga Lantbrukshögskolans Annaler 22, 139-145

Hyden S (1961) Determination of the amount of fluid in the reticulo-rumen of the sheep and its rate of passage to the omasum. Kungliga Lantbrukshögskolans Annaler 27, 51-79

Michell AR, Moss P, Hill R, Vincent IC, Noakes DE (1988) The effects of pregnancy and sodium intake on water and electrolyte balance in sheep. Br Vet J 144, 147-157

Olsson K, Benlamlih S, Dahlborn K, Fyhrqvist F (1982) Effects of water deprivation and hy- perhydration in pregnant and lactating goats. Acta Physiol Scand 115, 361-367

Weston RH (1979) Digestion during pregnancy and lactation in sheep. Ann Rech Vét 10, 442-444

Wintour EM, Coghlan JP, Congiu M, Grim CE, Laurence BM, Meehan PJ, McDougall JG, Scoggins BA (1987) Cardiovascular responsiveness to arginine vasopressin in waterloaded and sodium-depleted pregnant and non-pregnant sheep. Clin Exp Pharmacol Physiol 14, 319-326 